\title{
POPOVICIU TYPE INEQUALITIES VIA GREEN FUNCTION AND GENERALIZED MONTGOMERY IDENTITY
}

\author{
SAAD IHSAN Butt, Khuram Ali Khan AND Josip PEČARIĆ
}

\begin{abstract}
We obtained useful identities via generalized Montgomery identity, by which the inequality of Popoviciu for convex functions is generalized for higher order convex functions. We investigate the bounds for the identities related to the generalization of the Popoviciu inequality using inequalities for the Čebyšev functional. Some results relating to the Grüss and Ostrowski type inequalities are constructed. Further, we also construct new families of exponentially convex functions and Cauchy-type means by looking at linear functionals associated with the obtained inequalities.
\end{abstract}

Mathematics subject classification (2010): Primary 26D07, 26D15, 26D20, 26 D99.

Keywords and phrases: Convex function, divided difference, generalized Montgomery identity, Čebyšev functional, Grüss inequality, Ostrowski inequality, exponential convexity.

\section{REFERENCES}

[1] A. Aglić Aljinović, J. PeČarić, And A. Vukelić, On some Ostrowski type inequalities via Montgomery identity and Taylor's formula II, Tamkang Jour. Math., 36, 4 (2005), 279-301.

[2] S. N. Bernstein, Sur les fonctions absolument monotones, Acta Math. 52 (1929), 1-66.

[3] P. Cerone, S. S. Dragomir, Some new Ostrowski-type bounds for the Čebyšev functional and applications, J. Math. Inequal. 8, 1 (2014), 159-170.

[4] L. Horváth, K. A. KhAN AND J. PeČARIĆ, Combinatorial Improvements of Jensens Inequality / Classical and New Refinements of Jensens Inequality with Applications, Monographs in inequalities 8, Element, Zagreb, 2014.

[5] J. JAKŠETIC AND J. PeČARIĆ, Exponential Convexity Method, Journal of Convex Analysis. 20, 1 (2013), 181-197.

[6] J. JAKŠEtIĆ, J. PEČARIĆ, A. PERUŠIĆ, Steffensen inequality, higher order convexity and exponential convexity, Rend. Circ. Mat. Palermo. 63, 1 (2014), 109-127.

[7] K. A. Khan, J. PeČArić AND I. Perić, Differences of weighted mixed symmetric means and related results, Journal of Inequalities and Applications, 2010, Article ID 289730, 16 pages, (2010).

[8] K. A. KhAn, J. PeČARIĆ AND I. Perić, Generalization of Popoviciu Type Inequalities for Symmetric Means Generated by Convex Functions, J. Math. Comput. Sci., (to appear).

[9] C. P. NiculesCU, The Integral Version of Popoviciu's Inequality, J. Math. Inequal. 3, 3 (2009), 323 328.

[10] C. P. Niculescu And F. Popovici, A Refinement of Popoviciu's Inequality, Bull. Soc. Sci. Math. Roum. 49, 97 (2006), 285-290.

[11] D. S. Mitrinović, J. E. PeČArić, AND A. M. FinK, Inequalities for functions and their Integrals and Derivatives, Kluwer Academic Publishers, Dordrecht, 1994.

[12] J. PeČARIĆ And J. Perić, Improvement of the Giaccardi and the Petrović Inequality and Related Stolarsky Type Means, An. Univ. Craiova Ser. Mat. Inform. 391 (2012), 65-75.

[13] J. Pečarić, F. Proschan and Y. L. Tong, Convex functions, Partial Orderings and Statistical Applications, Academic Press, New York, 1992.

[14] T. Popoviciu, Sur certaines inégalités qui caractérisent les fonctions convexes, Analele Ştiinţifice Univ. “Al. I. Cuza”, Iasi, Secţia Mat. 11 (1965), 155-164. 
[15] P. M. Vasić And Lu. R. Stanković, Some inequalities for convex functions, Math. Balkanica. 6, 44 (1976), 281-288.

[16] D. V. Widder, Completely convex function and Lidstone series, Trans. Am. Math. Soc. 51 (1942), 387-398. 